\title{
An Analysis on Students' Perception of the Application of Journalist Questions in Teaching Writing
}

\author{
Muhamad Saopi
}

Hamzanwadi University, Indonesia

Correspondence: Muhamad Saopi, Indonesia. e-mail: muhamadsaopi25@gmail.com

Received: Augustus 01, 2018

doi: 10.29408/veles.v3i1.1050.g733
Accepted: Augustus 21, $2018 \quad$ Online Published: September 1, 2018

URL: http://dx.doi.org/10.29408/veles.v3i1.1050.g733

\begin{abstract}
This research aimed at knowing about the teaching learning process through journalist questions and students' perception of the application of journalist questions. This research is qualitative research. The subject of this research was the students of X IPS SMA NW Pringgabaya which consisted of 23 students. In addition, observation, questionnaire, and semi structured interview were used for collecting data. The finding revealed that the students have a good perception toward the implementation of journalist questions in teaching writing in the class. In addition, based on the result of observation, questionnaire and interview, the application of journalist questions was applied appropriately and the students' perception in teaching writing is good."
\end{abstract}

Keywords: students' perception, teaching writing, Journalist Questions

\section{Introduction}

English is one of international languages. It has been becoming one of languages taught in Indonesia as a foreign language. There are four skills that students need to learn when they try to learn English. Those are listening, speaking, reading and writing. Those skills should be mastered by the students to improve their ability in learning English. Talking about all of the four skills, writing is the most difficult skill that must be mastered by students. Irawati in Suma Ningsih (2016, p.2) stated that Writing is the most difficult and complicated language skill to be learned compared to other language skills,

Writing is one of the main language skills. It plays a major role in expressing one's ideas, thoughts, opinions, and attitudes. Through writing, people are capable of sharing ideas, feelings, persuading and convincing others. In addition there are many reasons to include writing in a second or foreign language syllabus. One important reason is that: writing helps learners learn. It helps them have a chance to adventure with the language, to go beyond what they have learned Reimes in Alfaki (2015, p.40). Hedge in Alfaki (2015, p.40) also states that a good deal of writing in the English language classroom is undertaken as an aid to learning; 
for example, to consolidate the learning of new structures or vocabulary or to help students remember.

Byrne in Alfaki (2015, p.41) states that certain psychological, linguistic and cognitive factors make writing a complex and difficult discourse medium for most people in both native and second language. While, Raimes in Alfaki (2015, p.41) thinks that "When students complain about how difficult it is to write in a second language, they are talking not only about the difficulty of finding the right words and using the correct grammar but also about the difficulty of finding and expressing ideas in a new language.

Teaching writing at the school is important to increase students' ability in academic writing. One of the activities used in teaching writing to students is Journalist Questions. Journalist Questions is one of the techniques for teaching Writing. It consists of 6 words (who, what, where, when, why and how) which are used by reporters to ask interviewees. Those words can stimulate the students to generate their ideas in writing.

Urquhart and McIver in Kurniyasari (2016, p.2), "Journalists' Questions (who, what, where, when, why and how), or the questions that are referred to as the five Ws and one $\mathrm{H}$, have been the mainstay of newsrooms across the country. The first word is who. "Who" is used to explore about the person in the news. The second word is what. "What" is used to explore about something happened in the news. The third word is when. "When" is used to explore about the time in the news. The fourth word is where. "Where" is used to explore about the location of the news. The fifth word is why. "Why" is used to explore about cause and result of the news. The sixth word is how. "How" is used to explore about how is something happened. Students can use those words to explore their idea in writing. It can help them to explore their idea in covering the whole story of writing.

Therefore, in this research, the present researcher was interested in exploring the process of teaching writing through journalist questions as well as analyzing the students' perception to the application of journalist questions.

\section{Method}

This research is belongs to a qualitative descriptive as the method of the research. Ary (2005, p.426) defines descriptive qualitative research is designed to obtain information concerning the current status phenomena. In qualitative research, there is little or no statistic. Cristine Marlow stated that qualitative the interpretive approach generally uses words (qualitative data) rather than numbers or concepts that can be quantified (qualitative data), rich description of phenomena can be produced. There is a systematic way of observing the events, collecting data, analyzing information, and reporting the results over a long period of time.

\subsection{Participants}

The participants of this research were consisted of twenty three (23) students of the eleventh grade of SMA NW Pringgabaya. This participants were taken randomly by using cluster random sampling technique. 


\subsection{Data Collection}

\subsubsection{Instrument of Collecting Data}

There were three instruments that the present researcher use for collecting the data, those are; observation list, interview guide, and questionnaire

\section{Observation list}

With the observation list it was expected that the observations run systematically, the present researcher did some steps while doing observation in the classroom those are ; 1) determining the variable, in this case the present researcher took two variable to be observed those are the teacher and the students, 2) determining the indicator for each variable, in this case the variable for the teacher is to know how is the application of journalist questions in teaching writing, meanwhile for the students were to know the students' perception to the application of journalist questions in teaching writing, 3) specifying the items of the observation statement, 4) determining how to record the data, in this case the present researcher decided to use mark to fill the column.

\section{Interview guide}

There were some steps that the present researcher done during the process of collecting data through the interview those are; 1) Determine the type of interview to be performed, at this steps the present researcher decided to use semi structured interview to gathering the data, 2) Prepare the appropriate tape recorder, the present researcher prepared smart phone as a tool to record the students' answer.

\section{Questionnaire}

The present researcher used questionnaire to collect the data. The questionnaire consisted of twenty one items. The present researcher made the questionnaire from some consideration which related to the application of journalist questions and the students' perception to the application of journalist questions in teaching writing. The items of questionnaire were classified into three categories. They can be seen in the following list: a) students' capability, b) students' feelings, c) students' interest, the researcher analyzed the data from questionnaire filled by participants manually.

\subsubsection{Techniques for Collecting Data}

\section{Observation}

Observation is a technique that involves systematically selecting, watching and recording behavior and characteristics of living beings, object or phenomena. The ways in doing observation were: a) the present researcher prepared the concept of observation form; b) the researcher joint in the classroom, c) the present researcher did observation in the classroom. By using observation guide, the present researcher observed teachers' steps when ombaining journalist questions to teach writing, and the students perception to the application of journalist questions, meanwhile the present researcher use the camera and sound recorder to make the document refers to photo and video. The present researcher conducted the observation in SMA NW Pringgabaya.

\section{Interview}

An interview is a conversation for gathering information. A research interview involves an interviewer who coordinates the process of the conversation and asks questions, and an 
interviewee who responds to those questions (Easwaramoorthy \& Zarinpoush, 2006. p.6). Easwaramoorthy \& Zarinpoush also stated types of interview, such as structured interview, semi-structured and unstructured interview.

The present researcher obtained the data from the semi-structured interview. The interview aims at knowing about the application of journalist questions in teaching writing and the students' perception in teaching writing.

\section{Questionnaire}

Questionnaire is a form containing a set of questions. It used to get information from students before and after classroom action research. The present researcher asked 21 questions about the application of journalist questions and the students' perception in writing ability through journalist questions in order to get data about students' perception to the application of Journalist Questions for learning English particularly in teaching writing.

\subsection{Data Analysis}

Nasution (1998 in Sugiono 2011, p.336) stated that data analysis is started from setting and explaining the problem, before going to the field and continued to reporting the result of the research. In fact, data analysis in qualitative research is an ongoing activity that occurs throughout the investigative process rather than after process.

Additionally, the present researcher described the process during the actions in forms of note from the observation, interview transcripts, and questionnaire. Firstly, the researcher looked up the findings as genuine data. Then, the researcher analyzed the description of opinions, performances, and the results of the research. Secondly, the present researcher classified the data into two classifications based on and to answer; the research questions, those are, the application of journalist questions in teaching writing and the students' perception of the application of journalist questions in teaching writing. The present researcher then verified the data by reporting the result to show the students' perception and the application of journalist questions in teaching writing.

In addition, Triangulation was used in this research in purpose of avoiding subjectivity and also maintaining trustworthiness in analyzing the data. It was performed by providing genuine data using questionnaire, observation checklists, and interview transcripts. The triangulation was applied by performing interviews with the students and also observations during the classroom research.

\section{Findings}

\subsection{The Application of Journalist Questions in Teaching Writing}

Based on the observation that was conducted by the present researcher in SMA NW Pringgabaya, the way teacher taught the students using Journalist Questions was structurally and suitable with the scheme. Before the teacher explained the main materials, firstly, the teacher greeted and led the students' to recite Shalawat Nahdhatain together. After praying the teacher checked the students' attendance to make a good atmosphere and relation between the teacher and students. The teacher also gave the students brain storming. The brain storming was an individual activity where the teacher showed some pictures on LCD, and the 
students tried to make some questions according to the pictures. At this step the teacher used some pictures such as, Pizza, Dilan, Etc, These were that part of Pre activity which was done by the teacher.

The main activities were group discussion. Here the teacher divided the students' into some groups by using collective grouping; each group consisted of five and six students. After grouping the students, the teacher showed the students an example of recount text and ask them to discuss the meaning, the generic structure, the language features, etc, with their friend.

After having a group discussion, the teacher briefly explained about $5 \mathrm{~W}+\mathrm{H}$ questions which are usually used in Journalist Questions, and the teacher also helped the students' to answer the $5 \mathrm{~W}+\mathrm{H}$ questions that are suitable to the text on the LCD. It is the main Activity which was done by the teacher.

To assess the students' comprehension during the class, the teacher asked the student some questions such as; 1 . Where did you go last vacation?, 2. What did you do then? 3. With whom?, 4. When did you do the action? 5. Why did you end the action? After answering those questions, the teacher continued to ask the students to generate their answer into a good paragraph. After they wrote a story, the teacher instructed the students to submit their recount text directly.

In addition the result of interview showed that journalist questions are interesting method. From fifteen students chosen as the sample to be interviewed by the researcher, it showed that most of them agreed that Journalist Questions should be used to teach writing in the classroom. As the participant said, "I absolutely agree Journalist Questions to be applied in classroom because as far as I know writing is boring skill and we don't know what we need to write. Writing our past experience by Journalist Questions method made us easier to write because the idea that we write is already in our mind", and since the teacher taught us, it is interesting and fun. It is not awkward as always as we did. The teacher showed us Dilan and Milea picture on the LCD, and also the teaching step seems easy to understand"

Furthermore, the interview result from some of the students is they were still confused how to write their own past experience based on the structure. As what the one of them said, "Writing my past experience is too difficult. It is not about the structure but lack of vocabulary, and some words in English have different sound with the spelling etc.".

\subsection{Students' Perception of the Application of Journalist Questions in Teaching Writing}

During the class the students seems interested in teaching learning process. It was seen from the students who were active in the group discussion by sharing their ideas to their friends. In addition, the students seemed to be confident to answer the teacher questions when there were some questions asked by the other students from the other groups.

The atmosphere during the teaching learning was warm enough; it can be seen from how the students kept their attention to the teacher explanation. It seemed to be easier to the students to understand the teacher instruction, even though some of the students did not take a part during the class, they seems quite behind their friends.

In addition, the present researcher classified the questionnaire data into three categories; those are the students' feeling, students' interest, and the students' capability. 
Some of the students found some difficulties in arranging their own concept into paragraph, but they did not give up easily, and they face their difficulties by asking their friends. At the time the teacher instruct them to work individually, and the students look very interested to rearrange their answer into paragraph. It can be seen from the result of the questionnaire, there were 10 items in the questionnaire related to the students' capability in writing recount text. Surprisingly most of the students agreed that the application of journalist questions helped them to improve their capability in writing recount text.

Moreover the teaching learning process by implementing journalist questions fun enough. It could be seen from the students' response in the questionnaire. There were 9 items in the questionnaire related to the students' feelings, and the students were agree that they were happy, motivated, and satisfied with the teaching learning process by implementing journalist questions.

Finally, there were 2 items of the questionnaire related into the students' interest. Amazingly, most of the students agreed that the application of journalist questions in teaching writing was interesting because it was not confusing them in writing their own recount text. The application of journalist questions in teaching writing is not only interesting the students but also adding their passion to write their own recount text.

In conclusion there were 21 items of Questionnaire and had been answered by 23 students as the sample, the researcher could calculate it, $23 \times 21$ become 483 , so the researcher got 483 points of answer from questionnaire, In this case, there were $28,36 \%$ students who strongly agree, 52,56\% students who agree, $22,98 \%$ students who just so, $6,00 \%$ students who disagree, and $0,20 \%$ students who absolutely disagree, based on these point the researcher could conclude that the students mostly had a good perception.

\section{Discussion}

According to Brown (2001) there are twelve principles of language teaching and the twelve principles are mapped into three parts: Cognitive, Affective, and Linguistic. cognitive is generally associated with mental and intellectual functioning, Affective aspect plays an important role in determining the level of success in learning, work, or other activities. Affection refers to emotions or feelings, Linguistic focuses on the language itself and how learners understand complex linguistic systems.

Further to Brown (2001, p. 61) stated that successful language learners in their realistic appraisal of themselves as vulnerable being yet capable of accomplishing task, most educator shows a conducive teaching learning process into; 1) create the atmosphere in the classroom that encourage the students to try the target language, 2) provide an appropriate challenges, 3) help your students to understand, 3) respond your students.

In addition, in teaching learning process teachers have to perform demonstrating, motivating, and provoking, supporting, responding, and evaluating before, during, and after student writing (Hamer in Hastuti and Nugroho, p.7).

Based on the observation that was conducted by the present researcher, in applying journalist questions, the teacher put the students into proper activities which means the teacher fulfilled the criteria of realistic appraisal in teaching and learning process. 
Additionally the students were really enthused to participate. However, some problems were found for the students such as lack vocabulary, and some words in English that have different sound from the spelling. To solve the problems the teacher helped the students by letting them to choose their easiest and shortest experience that they ever had. Most of the students in class chose Going to the Rice field for helping their parent as their topic. In addition, the students also got difficulties in translation. The teacher helped the students to translate some words that they could not translate into English, and they were suggested to consult dictionary.

Overall, from the observation, interview, and questionnaire, the present researcher could say, the application of journalist questions in teaching writing was properly conducted by the teacher which finally resulted positive perception from the students. Thus, the present researcher assumes that the positive perception of learning comes from instructional process.

\section{Conclusions}

The present researcher concluded that Journalist Questions can be used as alternative way to teach writing. In the additional Journalist Questions is interesting the students to learn English, not only interested the students' but also motivated the students to learn writing. The implement of Journalist Questions can help the students to reduce their boredom in writing class. As the result, the students can be more active in teaching learning process. Besides being interesting, it is also motivating for students to learn writing.

\section{References}

Alfaki, Ibrahim Mohamed. (2015). University students' english writing problems: diagnosis and remedy. Sudan: Nile Valley University Atbara. retrieved from 2 march 2018. http://www.eajournals.org/wpcontent/uploads/University-Students-English-WritingProblemsDiagnosis-and-Remedy.pdf

Dewi Tri Hastuti and Nugroho, Him'mawan Adi. (2016). The use of pen pal project to teach writing skill of recount text to the tenth grade students of SMA 1 Trenggalek. Surabaya State University. http://jurnalmahasiswa.unesa.ac.id/index.php/retain/article/view/15036

Puspa, Kurniasari. (2016). the effectiveness of journalist question technique to improve students' writing skill in narrative to the eight grade students of SMP N 19 Semarang in the academic year 2014/2015, retrieved from 2 march 2018. http://journal.unnes.ac.id/sju/.index.php/elt

Suma, Ningsih. (2016). Guided Writing to Improve the Students' Writing Ability of Junior High School Students retrieved from 2 march 2018 http://www.efljournal.orge-ISSN: 2502-6054, p-ISSN: 2527-5089

http://www.efljournal.orge-ISSN: 2502-6054, p-ISSN: 2527-5089 